\title{
Phenology, fruit set and dispersal of Cordia multispicata Cham., an important weed shrub of abandoned pastures in eastern Amazonia
}

\author{
IMA CÉLIA GUIMARÃES VIEIRA ${ }^{1}$ and JOSÉ MARIA CARDOSO DA SILVA²
}

(recebido em 02/01/95; aceito em 27/09/96)

\begin{abstract}
Phenology, fruit set and dispersal of Cordia multispicata Cham., an important weed shrub of abandoned pastures in eastern Amazonia). The reproductive ecology of the distylous tropical shrub Cordia multispicata was studied in an abandoned pasture in Paragominas County, Pará state, Brazil. It is a common species in the Amazon basin where it occurs as a weed in open and disturbed habitats. C. multispicata has many flowers per inflorescence $(85 \pm 12)$ but $84 \%$ abort before fertilization. Flowering occurs throughout the year. Fruits are small, with a red fleshy pericarp (skin-pulp) attractive to birds. Fruit set is lower during the dry season (less than $30 \%$ ) and higher during the rainy season when there are many visits of insects to the flowers. Fruiting has a peak between the end of the dry season and the middle of the rainy season. Nineteen bird species were observed foraging for the fruits of $C$. multispicata, and $79 \%$ of those species can be considered as potential dispersal agents. The efficient seed dispersal and aggregated spatial distribution associated with some characteristics of the dispersors greatly contributed to the success of this species in abandoned pastures of eastern Amazonia.

RESUMO - (Fenologia, relação fruto-flor e dispersão de Cordia multispicata Cham., uma importante planta invasora de pastagens no leste da Amazônia). A ecologia reprodutiva do arbusto Cordia multispicata foi estudada em uma pastagem abandonada após uso intensivo, em Paragominas, estado do Pará. Esta espécie é muito comum na Amazônia, onde aparece como invasora em habitats abertos ou perturbados. Possui flores distílicas e uma grande quantidade de flores por inflorescência ( $85 \pm 12$ ), sendo que $84 \%$ aborta antes de ser fecundada. A floração se estende durante o ano inteiro. Os frutos são pequenos, de coloração vermelha e pericarpo carnoso, bastante atraentes para aves. A relação fruto-flor é baixa na estação seca, alcançando valores mais elevados na época chuvosa, quando há mais freqüentes visitas de insetos nas flores. A frutificação ocorre no final da estação seca e se estende até meados da estação chuvosa. Foram encontradas 19 espécies de pássaros forrageando os frutos de $C$ multispicata, sendo que $79 \%$ dessas espécies são dispersores efetivos das sementes desta espécie. O eficiente modo de dispersão das sementes, associado com algumas características dos dispersores, parece ser fundamental no sucesso da espécie nas pastagens abandonadas da Amazônia oriental.
\end{abstract}

Key words - Abandoned pastures, Amazonia, Cordia multispicata, reprocuctive biology, weed ecology

\section{Introduction}

In the last decades large areas of tropical wet forests in eastern Amazonia have been converted to pastures. Consequent1y, many species are declining whereas others are expanding their populations and distribution in these new man-generated habitats. Previous work (Uhl et al. 1988) has shown that forest regeneration after pasture abandonment depends on the intensity of disturbance. In some pasture landscapes intensive1y used for more than ten years only 20 tree and vine species (5\% of the original flora) are present while more than 100 weeds can be found. These weedy species are well adapted for the occupation of disturbed habitats, and often share several life-history characteristics: rapid

1. Museu Paraense Emilio Goeldi/CNPq/MCT, Departamento de Botânica, Caixa Postal 399, 66017-970 Belém, PA, Brasil.

2. Museu Paraense Emilio Goeldi/CNPq/MCT, Departamento de Zoologia, Caixa Postal 399 , 66017-970 Belém, PA, Brasil. colonization of disturbed successional habitats, high reproductive rates, effective dispersal of propagules, early and continuous reproduction and rapid somatic growth.

Cordia multispicata Cham.(Boraginaceae) is one of the most common weeds of early succession in eastern Amazonia. Grazing and fire facilitate its initial establishment and growth in active pastures but also lead to reduced high mortality of adult plants. Once established, C. multispicata grows rapidly, spreading out over the surrounding grasses and forbs (Vieira et al. 1994).

Recent studies (Uhl et al. 1991, Vieira et al. 1994) have showed that the presence of trees in abandoned pastures is associated with patches of $C$. multispicata and other pioneer species, which provide micro-environmental conditions for the establishment of woody species. However, much basic information about the life history of these pioneer species is still unknown. Such information are important for understanding the relationships between life-history characteristics and colonization 
success as well as the large-scale succession process occurring in eastern Amazonia.

In this paper, descriptive information on the life history of $C$. multispicata in an abandoned pasture in eastern Amazonia is provided. It includes spatial distribution, annual phenological cycle, floral biology and seed dispersal and a discussion about which attributes of this species enable it to be a successful colonizer in Amazonian abandoned pastures.

\section{Material and methods}

Study area - The study area is localized at Vitoria Ranch, Paragominas County $\left(2^{\circ} 55^{\prime} \mathrm{S}, 47^{\circ} 35^{\prime} \mathrm{W}\right)$, Pará, Brazil. The region has Köppen's Aw climate type (Sá 1986) and an average annual rainfall of $1700 \mathrm{~mm}$. There are two distinct seasons: a wet season from December to May, and a dry season from June to November. The average monthly rainfall during the dry season is lower than $100 \mathrm{~mm}$

The Vitoria Ranch has a mosaic of distinct vegetation types, including evergreen lowland rain forest, second-growth forest, abandoned pastures and improved pastures. The studies were undertaken in a 7.25 ha area of abandoned pasture, which was originally planted in 1971 with the grass Panicum maximum and abandoned in 1984. The invasion of weed species (e.g. Paspalum millegrana Schrad., Rolandra argentea Rottb., Sida rhombifolia L., Stachytarpheta cayennensis (L.C. Rich.) Vahl.) took place while the pasture was in use and this is one of the reasons for its decline in productivity. Before being abandoned, the pasture was grazed by cattle in a rotation regime, with one to four animals per ha, and was submitted to periodic weed control by cutting and burning and eventually by the application of herbicides. During these studies, the former pasture was dominated by Cordia multispicata Cham., Panicum maximum Jacq. and Solanum critinum Lam., among other species.

Plant material - Cordia multispicata Cham. (Boraginaceae; common Portuguese name: "maria-preta") is a perennial weed whose geographical distribution encompasses the Amazonia and Caatinga regions of Brazil (Taroda \& Gibbs 1986). On abandoned pastures, $C$. multispicata is a shrub up to $2 \mathrm{~m}$ tall with patchy distribution, while in secondary forests C. multispicata is a vine, whose height depends on the supporting tree. The inflorescence are terminal axillary or pedunculate. They may be solitary or in clusters of two or three. The flowers are hermaphroditic, white, with very pleasant smell, and show dimorphism in relation to style and stamen length (figure 1). The individuals can be long-style ("Pin" morph), short-style ("Thrum" morph) or, more rarely, intermediates. The fruits of $C$. multispicata are conical, with a red and fleshy pericarp. Mean fruit size is $4.8 \times 3.5 \mathrm{~mm}$ and the mean weight is $0.01 \mathrm{~g}$.

Ecological studies - The studies on population density, floral morphology, fruit set and phenology were made between April 1989 and March 1991. Seed dispersal was studied from December 1989 to December 1990.

To evaluate the abundance and spatial distribution of $C$. multispicata, the study area was divided into 60 plots of $25 \mathrm{~m} \mathrm{x}$ $50 \mathrm{~m} .30 \%$ of these plots were sorted and all individuals $\geq 1 \mathrm{~m}$ tall were counted and mapped. The spatial pattern distribution of $C$. multispicata was tested for the fit to Poisson distribution using the index of dispersion (observed variance/ observed mean) according to procedures described by Krebs (1989).

The proportions of each morph in the population was estimated from 176 randomly selected reproductive individuals during November 1989. The flowering and fruiting phenologies of $C$. multispicata were determined through two-weekly observations of twenty individuals during twenty months. In each census, the presence of flowers or fruits in each individual was recorded. During the flowering, observations on the daily time and duration of flower opening were also made.

The animals that visited the flowers of $C$. multispicata were recorded from 30 reproductive individuals at each hour from 7:00 to $16: 00 \mathrm{~h}$, during 3 days in both rainy and dry seasons of 1989 (27 hours/season). The frequency of flower visitants were observed in detail at every $10 \mathrm{~min}$ in both seasons by observing 8 "Pin" individuals and 9 "Thrum" individuals (among the 30 individuals) in the peak of daily flowering (between 7:00 and 10:00 a.m.), during 3 days. The insect species were firstly classified by order and, using a combination of characters from external morphology and coloration patterns by morphospecies The specimens were deposited in the Entomological Collection of the Museu Goeldi, Belém, Brazil, for identification.

The fruit set was observed in two wet (December-May) and two dry (June-November) seasons. In each season, 10 inflorescence of 10 "Pin" and 10 "Thrum" plants $(2$ x 100 inflorescences in total) were marked. Afterwards, at four-day intervals the numbers of open flowers, wilted flowers and stage of fruit formation were observed in each inflorescence. Fruit set was later calculated by dividing the total number of developed fruits by the total number of opened flowers per inflorescence.

The role of birds in the dispersal of fruits of $C$. multispicata was examined using a combination of field observations and mist netting near fruiting individuals. For each bird foraging for at a fruiting individual, the species and food handling behavior were recorded. To determine if the bird species observed were dispersing seeds of $C$. multispicata, the fruit-eating birds were captured in mist nets ( $2.6 \mathrm{~m}$ height, $12 \mathrm{~m}$ length, $36 \mathrm{~mm}$ mesh) placed at random in the study area. Upon capture, they were isolated in individual paper sacks for two or more hours to allow collection of their faeces. Birds were released after identification and banding. The seeds found in the birds' faeces were identified through comparison with a reference collection. Finally, the seeds of $C$. multispicata obtained in this way were examined for their germination potential in a greenhouse over a period of 30 days and compared with the germination of seeds collected directly from the fruits.

\section{Results}

Spatial distribution - The estimated density of $C$. multispicata in our study area was 81 individuals/ha. The spatial distribution is aggregated (Index of dispersion $=2.9, \mathrm{X}^{2}=27.4, \mathrm{p}<0.005$ ), with the individuals dispersed in variable-sized patches linked by narrow corridors. The "Thrum" individua1s were more common $(52.2 \%)$ than the "Pin" ones $(47.8 \%)$, but this difference is not statistically significant $\left(\mathrm{X}^{2}=0.36, \mathrm{p}=0.546\right)$.

Phenology - In general, $C$. multispicata produces flowers and fruits during almost all year (figure 2), 


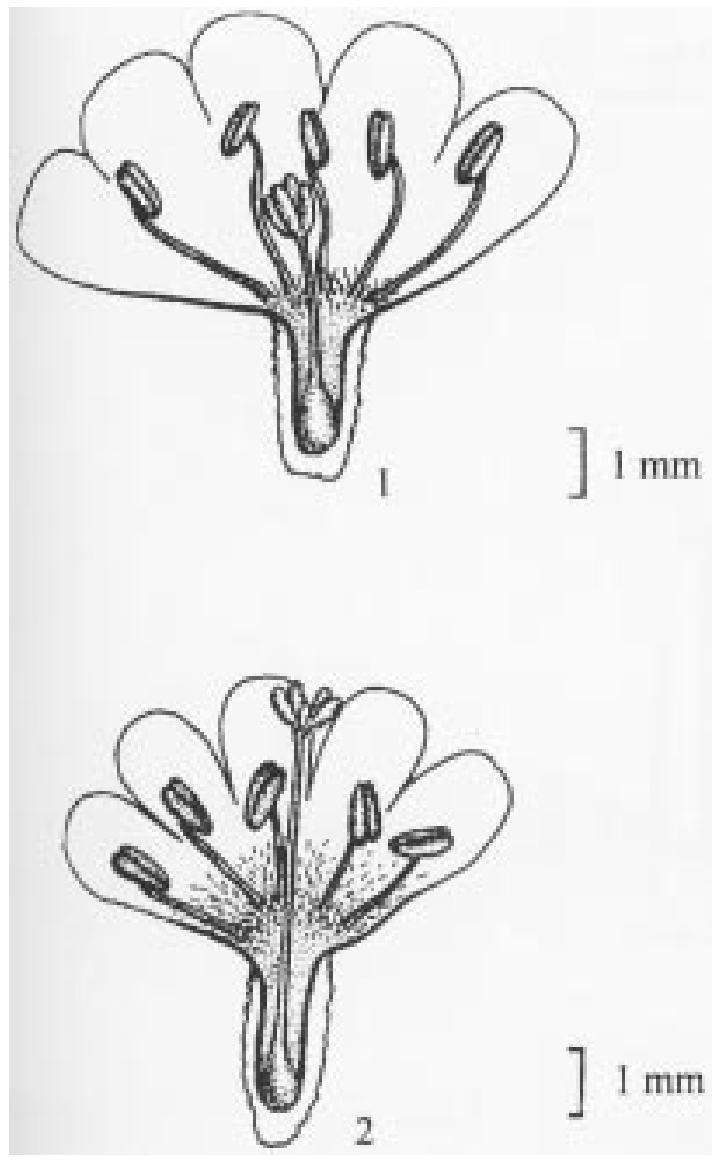

Figure 1. Floral morphs in C. multispicata. (1) Short-style ("Pin"), (2) Long-style ("Thrum").

with a peak between the end of the dry season and the middle of the wet season. In 1989, when the monthly average precipitation was above $400 \mathrm{~mm}$, there was an abrupt halt in fruit production. Afterwards, the fruit production remained low until it again reached a new peak, during the next rainy season. The degree of flowering and fruiting synchrony among the individuals is higher during the rainy season. During the 24 months of observations, the individuals flowered during 11.15 \pm 3.56 months while these same individuals fruited for only half of this period $(5.75 \pm 2.48)$.

Floral biology - The flowers of $C$. multispicata open early in the morning (5:00 to 6:00 a.m.) and stay opened for 4-6 days. The mean number of flowers/ inflorescence per individual is $85 \pm 12$, but
Table 1. Number of flowers and fruits per inflorescence (Mean \pm standard deviation) and fruit set of the two floral morph of $C$. multispicata in dry and wet seasons in an abandoned pasture of eastern Amazonia ( $\mathrm{N}=100$ inflorescences and infrutescences / season)

\begin{tabular}{ccrrr}
\hline Season & Morph & $\begin{array}{c}\text { No. Flowers/ } \\
\text { inflorescence }\end{array}$ & $\begin{array}{r}\text { No. Fruits/ } \\
\text { infrutescence }\end{array}$ & $\begin{array}{r}\text { Fruit set } \\
(\%)\end{array}$ \\
\hline \multirow{2}{*}{ Dry } & "Pin" & $12.04 \pm 1.74$ & $2.98 \pm 1.77$ & 24.75 \\
& "Thrum" & $10.89 \pm 2.25$ & $1.19 \pm 0.57$ & 10.93 \\
Wet & "Pin" & $18.05 \pm 1.71$ & $8.74 \pm 0.80$ & 48.42 \\
& "Thrum" & $16.71 \pm 1.63$ & $10.33 \pm 0.97$ & 61.82 \\
\hline
\end{tabular}

the percentage of flower abortion before anthesis is very high (compare this mean with the means of the open flowers in table 1). The mean number of opened flowers per inflorescence is higher in the "Pin" morphs than in the "Thrum" ones in both seasons (wet season, $\underline{\mathrm{t}}=4.0, \mathrm{p}<0.001$; dry season, $\underline{\mathrm{t}}=5.6$, $\mathrm{p}<0.001)$. The mean number of opened flowers by inflorescence is higher in the wet season than in the dry season in both morphs ("Pin", $\mathrm{t}=24.6, \mathrm{p}<0.001$; “Thrum", $\underline{\mathrm{t}}=20.9, \mathrm{p}<0.001)$.

Twenty-one morphospecies of insects were observed visiting the flowers of $C$. multispicata (Lepidoptera, 8 spp.; Hemiptera, 6 spp.; Diptera, 5 spp.; other orders, 2 spp.), but only one species of Diptera was observed with pollen on its feet. The mean number of visitant insects at flowers during each 10 minute interval is higher in the wet season $(4.94 \pm 1.39)$ than in the dry season $(2.18 \pm 1.01)$ $(\mathrm{t}=9.08, \mathrm{p}<0.001)$. The frequency of insect visits in this period also was greater in wet season $(30.3 \pm$ 14.69) than during the dry season $(7.2 \pm 4.69)$ $(\underline{t}=8.47, \mathrm{p}<0.001)$. No differences exist between "Pin" and "Thrum" morphs related to frequency of visits and type of visitant insects.

Fruit set - The number of early fruits (with the ovary not well developed) in $C$. multispicata varies between 23 to 26 per individual. The maturation of these fruits is non-uniform and there is a great frequency of abortion amongst the early fruits. Fruiting success followed the same pattern as flower success (table 1); It is higher in the "Thrum" individuals than in "Pin" ones in either season (wet season, $\underline{t}=12.6, p<0.001)$; dry season, $\underline{\mathrm{t}}=9.6$, $\mathrm{p}<0.001)$ and also higher in the wet season than in the dry season independent of the morph ("Thrum", $\underline{\mathrm{t}}=29.6, \mathrm{p}<0.001$; "Pin", $\underline{\mathrm{t}}=81.2, \mathrm{p}<0.001)$. 


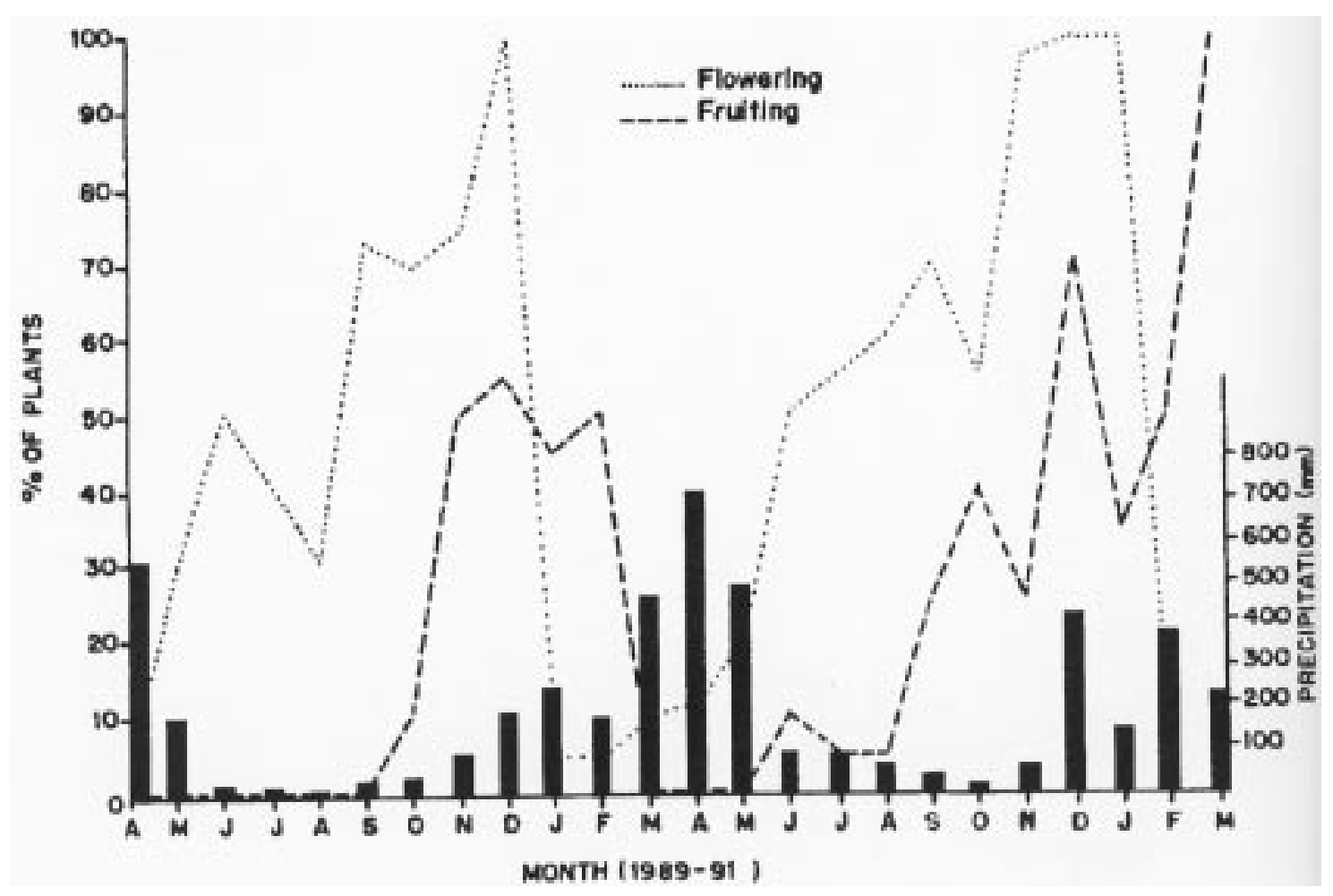

Figure 2. Reproductive phenology of C. multispicata in an abandoned pasture of eastern Amazonia.

Dispersal - Nineteen bird species were recorded consuming fruits of $C$. multispicata (table 2). The mass of these bird species varies between 10 and 300 $\mathrm{g}$ but sixteen species $(82.2 \%)$ have mass under $50 \mathrm{~g}$. The majority $(89.4 \%)$ of these species ingest the entire fruit, while Sporophila americana and Volatinia jacarina ingest only the pericarp, dropping the seeds under or near the source plant. Most of the species $(78.9 \%)$ that ingest the entire fruit, voided the seeds without any damage, but the doves (Columbina spp. and Zenaida auriculata) and Laterallus viridis voided the seeds completely broken and therefore inviable.

The results of germination tests in greenhouse suggested a high percentage of germination of seeds of $C$. multispicata $\left(\mathrm{X}^{2}=20.8, \mathrm{p}<0.001\right)$, that passed through the bird's digestive system ( $92 \%, \mathrm{~N}=25$ ) when compared to germination of uneaten seeds $(43 \%, \mathrm{~N}=150)$. Thus, most of the bird species $(73.9 \%)$ that consume fruits of $C$. multispicata may be considered as its potential dispersal agents.

\section{Discussion}

High establishment capacity in disturbed environments can be achieved by plants that exhibit characteristics such as self-compatibility and high dispersal capacity (Bazzaz \& Picket 1980). C. multispicata does not agree totally with this pattern since it has distylous flowers that are expected to show the same heteromorphic self-incompatibility recorded for other species of this genera (Johnston 1950, Percival 1974, Opler et al. 1975, Taroda \& Gibbs 1986). Heterostyly when associated with self-incompatibility may produce a low fruit set (Bentley 1979, Sobrevila et al. 1983, Kanashiro 1986). Thus, weak pollen flow between the two morph of C. multispicata might be one of the factors that determine the lowest fruit set during the dry season, when the activities of insects are reduced when compared with the wet season. The heterostyly can also increase crossing probability (Bentley 1979) and presumably might ensure sufficient genetic variability for the species survival in 
Table 2. Bir species that forage fruits os C. multispicata in an abandoned pasture of eastern Amazonia.

\begin{tabular}{|c|c|}
\hline $\begin{array}{l}\text { Family/ } \\
\text { Species }\end{array}$ & Body mass (g) \\
\hline \multicolumn{2}{|l|}{ CRACIDAE } \\
\hline Ortalis superciliaris & 300.0 \\
\hline \multicolumn{2}{|l|}{ RALLIDAE } \\
\hline Laterallus viridis & 75.0 \\
\hline \multicolumn{2}{|l|}{ COLUMBIDAE } \\
\hline Columbina passerina & 32.0 \\
\hline Columbina talpacoti & 40.0 \\
\hline Zenaida auriculata & 110.0 \\
\hline \multicolumn{2}{|l|}{ TYRANNIDAE } \\
\hline Camptostoma obsoletum & 10.0 \\
\hline Elaenia flavogaster & 23.0 \\
\hline Myiodynastes maculatus & 50.0 \\
\hline Myiozetetes cayennensis & 22.0 \\
\hline Phaeomyias murina & 11.0 \\
\hline Tolmomyias flaviventris & 12.0 \\
\hline \multicolumn{2}{|l|}{ VIREONIDAE } \\
\hline Cyclarhys gujanensis & 28.0 \\
\hline \multicolumn{2}{|l|}{ EMBERIZIDAE } \\
\hline Saltator maximus & 40.0 \\
\hline Schistochlamis melanopis & 35.0 \\
\hline Sporophila americana & 13.0 \\
\hline Tachyphonus rufus & 35.0 \\
\hline Thraupis episcopus & 35.0 \\
\hline Thraupis palmarum & 25.0 \\
\hline Volatinia jacarina & 11.0 \\
\hline
\end{tabular}

environments such as abandoned pastures, which have great local and seasonal variation of physical and biotic factors. However, this hypothesis need to be examined with additional studies.

All possible dispersal vectors of the fruits of $C$. multispicata in the abandoned pasture can be regarded as "generalists" fruit-eating birds, since they include a high proportion of insects in their diets. Furthermore, these species generally consume small fruits with high concentration of water and carbohydrates (such as these of $C$. multispicata) available in large quantities in the second-growth habitats and abandoned pastures, rather than fruits rich in lipids and proteins (e.g. Lauraceae), available most frequently in mature forests. Similarly to $C$. multispicata, these bird species reach their highest population densities in the eastern Amazonia in anthropogenic habitats (Novaes 1973). In our study area they exhibited constant movements within and between all types of secondary habitats (Silva et al. 1996).

The success of $C$. multispicata in anthropogenic habitats of eastern Amazonia can only be explained by combining characteristics of the species itself (e.g., great survival potential in inhospitable sites, aggregated spatial dispersion, synchronic fruiting, effective dispersal of seeds) with those of its dispersal agents (e.g., high densities in anthropogenic habitats, extensive movements between these habitats). For example, the species' aggregate distribution and synchronized fruit production by the individuals can assure that a great quantity of fruits be available simultaneously for the birds in a given patch. This is an important factor that can compensate for $C$. multispicata's low individual fruit set - a consequence of limited pollen flow produced by insects. If this low fruit set were exhibited by isolated individuals or even randomly distributed individuals with asynchronic fruiting, the species could become less attractive for birds and thus reduce its dispersal efficiency. From this study we can conclude that although this tropical weed suffer from low fruit set, this is compensated by highly efficient avian dispersal of the seeds which are produced. At least in our study area, these characteristics allowed $C$. multispicata to be a dominant species in the early stages of succession in abandoned pastures. Further studies in the same region are necessary to evaluate if this pattern is shared with other abandoned pastures with different use histories.

Acknowledgements - We thank Christopher Uhl, Daniel Nepstad, John Proctor and Jon Fjeldsa for comments and discussion. We gratefully acknowledge Sabino, Aurélio, Jorge and Manoel Aviz for their field assistance as well as Eleni and Aquides for opening their home to us. Finally we express our thanks to Conselho Nacional de Desenvolvimento Científico e Tecnológico (CNPq) and National Geographic Society for the financial support.

\section{References}

BAZZAZ, F.A \& PICKETT, S.T.A. 1980. Physiological ecology of tropical succession: a comparative review. Annu. Rev. Ecol. Syst. 11:287-310.

BENTLEY, B.L. 1979. Heterostyly in Turnera trioniflora, a roadside weed of Amazon basin. Biotropica 11:11-17.

JOHNSTON, I.M. 1950. Studies in the Boraginaceae XIX. A noteworthy species from tropical America. B. Cordia sect. Geracanthus in Mexico and Central America. J. Arnold. Arb. 16:1-64. 
KANASHIRO, M. 1986. Reproductive biology of Cordia goeldiana a neotropical heterostylous species. Msc. Thesis, Faculty of North Carolina State University.

KREBS, C.J. 1989. Ecological methodology. Harper \& Row Publishers, New York.

NOVAES, F.C. 1973. Aves de uma vegetação secundária na foz do Amazonas. Publs. Avuls. Museu Goeldi 21:1-88.

OPLER, P.A., BAKER, H.G. \& FRANKIE, G.W. 1975. Reproductive biology of some Costa Rican Cordia species (Boraginaceae). Biotropica 7:234-237.

PERCIVAL, M. 1974. Floral ecology of coastal scrub in Southeast Jamaica. Biotropica 6:104-129.

SÁ, T. D. de A. 1986. Caracterização climática da Amazônia oriental. In Pesquisas sobre utilização e conservação do solo na Amazônia oriental (EMBRAPA/CPATU-GTZ, ed.). Belém, p.3-13.

SILVA, J.M.C., UHL, C. \& MURRAY, G. 1996. Plant succession, landscape management, and the ecology of frugivorous birds in abandoned pastures. Conservation Biology 10:491-503.

SOBREVILA, C., RAMIREZ, N. \& DE ENRECH, N.X. 1983. Reproductive biology of Palicourea fendleri and P. petiolaris (Rubiaceae), heterostylous shrubs of a tropical cloud forest in Venezuela. Biotropica 15:161-69.

TARODA, N. \& GIBBS, P.E. 1986. A Revision of the Brazilian species of Cordia subgenus Varronia (Boraginaceae). Notes Royal Botanical Garden, Edinburgh 44:105-140.

UHL, C., BUSCHBACHER, R. \& SERRÃO, E.A.S 1988. Abandoned pastures in eastern Amazonia. I. Patterns of plant succession. J. Ecology 75:663-681.

UHL, C.; NEPSTAD, D.; SILVA, J.M.C. \& VIEIRA, I.C.G. 1991. Restauração da floresta em pastagens degradadas Ciência Hoje 13:23-31.

VIEIRA, I.C.G., UHL, C. \& NEPSTAD, D.C. 1994. The role of the shrub Cordia multispicata Cham. as a "succession facilitator" in an abandoned pasture, Paragominas, Amazônia. Vegetatio 115:91-99. 